\title{
$2 \mathrm{t}$
}

PROJECT MUSE

\section{Venice Preserved by Thomas Otway (review)}

Angelina Del Balzo

Eighteenth-Century Studies, Volume 53, Number 2, Winter 2020, pp. 299-301 (Review)

Published by Johns Hopkins University Press

DOI: https://doi.org/10.1353/ecs.2020.0010

$\Rightarrow$ For additional information about this article https://muse.jhu.edu/article/747241 


\title{
THEATER REVIEW
}

\author{
Edited by Jennifer Thorn
}

ANGELINA DEL BALZO, Bilkent University

Thomas Otway, Venice Preserved. Directed by Prasanna Puwanarajah. Presented by the Royal Shakespeare Company at the Swan Theatre, Stratford-upon-Avon, UK. May 24-September 7, 2019. Design by James Cotterill. Lighting design by Jack Knowles. Sound design by George Dennis. Movement by Polly Bennett. Fights by Kate Waters. Video by Nina Dunn. Costumes by Sian Harris. Props by Lauren Simmonds. With Jodie McNee (Belvidera), Michael Grady-Hall (Jaffeir), Stephen Fewell (Pierre), John Hodgkinson (Antonio), Natalie Dew (Aquilina), Steve Nicolson (Renault), Les Dennis (Priuli), Kevin N. Golding (Duke of Venice), and ensemble.

Called "one of the first names in English drama” by Samuel Johnson, Restoration tragedian Thomas Otway has now all but disappeared from the repertoire, along with most of the period's major tragic dramatists. After dropping out of the repertoire in the late nineteenth century, Venice Preserved reemerged with a successful revival directed by Peter Brook at the Lyric Hammersmith in 1953, starring the legendary John Gielgud and Paul Scofield. Afterwards, it has enjoyed the occasional revival every decade or so, mostly in the United Kingdom. Director Prasanna Puwanarajah's summer 2019 production at the Royal Shakespeare Company presented a streamlined narrative that eschewed period specificity for a cynical take on the play's political stakes, emphasizing the personal relationships at its center.

At first glance, Venice Preserved seems like an odd choice for Puwanarajah's directorial debut at the RSC. As an actor, he has been outspoken about racist practices in British theater and film. In an interview with the Financial Times, he described the play as being "about crumbling city states that were once great empires, it's about the rise of the morally impure protagonist in that space, it's about idiots in power. . . It has incredible characters who are at the edges of a revolution." ${ }^{1}$ He remarks in the same interview that his everyday experience of racism has only gotten worse after the European Union referendum. In a political moment in which fascism is ascendant, the murky rebellion at the center of Venice Preserved 
speaks to a zeitgeist where lasting progress can feel elusive. Puwanarajah's take on the play's politics is one in which there is no side that offers a clear way towards a better future.

This vision of the play, described by Puwanarajah as "Restoration noir," was interpreted through a design rooted in cyberpunk à la "Blade Runner" (1982), an aesthetic developed in the eighties in a response to Japanese anime, sci-fi dystopia, new technologies in surveillance and gaming, and the wealth disparities from Thatcherism and Reaganomics. In many ways this is an inspired choice as a setting for a Restoration tragedy, as both cyberpunk and Restoration tragedy respond to periods of conservative reaction to previous political instability, rendered aesthetically through visual excess in art and fashion. A particularly evocative image connecting these disparate modes was when the conspirators don the Guy Fawkes masks from "V for Vendetta" (1982-89), Alan Moore and David Lloyd's graphic novel about an anti-fascist vigilante. The pop culture afterlife of the Gunpowder Plot referenced the other Popish Plot of 1678, a cyberpunk gesture to the antiCatholic paranoia that informed the play's premiere.

Puwanarajah's slimmed-down text intentionally avoided many of the "operatic qualities" (his words) that characterize Restoration tragedy, but the central emotional stakes remained the love between Jaffeir and Belvidera, played with intensity by Michael Grady-Hall and Jodie McNee, respectively. Jaffeir's sincerity is never in doubt, but his presentation here as a beta male in pleated khakis made apparent from the opening the weakness that lead him to offer Belvidera as collateral to the conspirators. Stephen Fewell's Pierre, in contrast, had charisma to burn; a disillusioned military officer, he appeared to be the only character who believed in idealistic rebellion. These three central performances elevate the conflict from Jaffeir's initial petulant reaction against his senator father-in-law, showing how his equally compelling but irreconcilable loyalties to his friend and his wife can only lead to tragedy.

The crowd-pleasing sections of the production were dominated by John Hodgkinson's Antonio, a Tory with a kink for whips and animal role-play, as he bellows for his "Nicky-Nacky" Aquilina (Natalie Dew), an S\&M sex worker in love with Pierre. Antonio's submission is solely sexual and superficial: he gets off on being punished by Aquilina (and also, in a fun ad-libbed moment, on an audience member helping him with a speech) because he believes their interactions can never become true political subjugation. In a scene straight from Otway, Antonio demanded to be spit upon and played as a dog. The audience laughter was in part from the surprise that the S\&M references appeared in Otway's dialogue, not only through modern costume and staging choices: the pleather may have been anachronistic, but the desires were not.

Puwanarajah's emphasis on the thriller aspects of the plot most affected the characterization of Belvidera. Unlike a she-tragic heroine, she was the steady, pragmatic counterpart to Jaffeir's emotional extremes, soothing him by singing "Big Rock Candy Mountain" and reaffirming their love. The production also eliminated references to Jaffeir and Belvidera's off-stage child, the subject of many of Otway's most anguishing speeches. I can't help but wonder if it also indicates the ways in which parenthood, and, especially, motherhood are sympathetic third-rails. Would Jaffeir and Belvidera's deaths have been viewed as selfish rather than tragic by contemporary audiences if they left behind an orphaned child? Despite these changes, Belvidera remained the focal point of the play's tragic ending. In a stark contrast to Jaffeir and Pierre's chaotic murder-suicide at the place of execution, 
Belvidera quietly dies alone in the middle of a rainy street. McNee's performance at the end was understated and moving, reinterpreting the emotional performances of Elizabeth Barry and her successors that made she-tragedy successful.

Unlike our Shakespearean counterparts, Restoration and eighteenth-century theater scholars are lucky to see one production of a tragedy in our lifetimes, let alone the opportunity to compare multiple productions. With the recent turn in performance studies towards liveness, as exemplified by an ASECS 2019 Theatre and Performance Studies Caucus panel on the topic, our continued reliance primarily on the printed text has obstructed our ability to theorize and interpret drama as embodied. Contemporary productions do not have to use historical stage practices to be useful to scholars; the different staging and performance choices by directors, designers, and actors can reveal new aspects of the work. For theater artists, staging Restoration tragedy also offers a representation of emotion unlike those offered by eras before and after the Restoration. In she-tragedy the actress is not relegated to supporting the male lead but is herself the tragic protagonist. As this fine staging abundantly showed, experiencing she-tragedies can help expand our sense of whose stories we deem worth privileging, an especially valuable after-effect of a good night in the theater in an era in which both the theater and academia are reckoning with these questions, both in our professions and in our texts.

\section{NOTE}

1. Interview referenced: https://www.ft.com/content/b8e77822-755f-11e9-b0ec-7dff87b9a4a2 